\title{
Effect of the Essential Oil of Clausena anisata (Rutaceae) and Palm Kernel Vegetable Oil on Engorged Females of Three Species of Ixodidae Cattle Ticks
}

\author{
Mollong Eyabana, PhD Student
}

Laboratory of Applied Entomology, Department of Zoology and Animal

Biology, Faculty of Science, University of Lomé, Lomé 01- Togo

\section{Nuto Yaovi, PhD, MC}

Laboratory of Applied Entomology, Department of Zoology and Animal

Biology, Faculty of Science, University of Lomé, Lomé 01- Togo, Environmental Biology, Pesticide Toxicology and Insect Ecology, Advanced School of Biology and Food Processing Techniques, Faculty of Science,

University of Lomé, Lomé 01- Togo

Bawa Rabiétou Akpéni, PhD

Kasseney Dodji Boris, PhD, MA

Gomina Mondjonnesso, PhD

Tozoou Panawé, PhD

Laboratory of Applied Entomology, Department of Zoology and Animal

Biology, Faculty of Science, University of Lomé, Lomé 01- Togo

Doi: 10.19044/esj.2018.v14n15p517 URL:http://dx.doi.org/10.19044/esj.2018.v14n15p517

\section{Abstract}

Improving and increasing livestock production system yield requires parasite control, especially ticks, which stifle the emergence of successful breeding units. Effective environmentally friendly and biological parasite control is urgently required. The purpose of this study was to evaluate the effects of the essential oil of Clausena anisata (Rutaceae) and of palm kernel vegetable oil compared to a reference chemical acaricide, flumethrin, on the biological parameters of the engorged females of three major tick species in the Maritime Region of Togo. The topical tests applied consisted respectively of depositing a drop of $75 \mu \mathrm{L}$ and $5 \mu \mathrm{L}$ of the crude extracts and their dilutions on the back of each female of Amblyomma variegatum, Rhipicephalus (Boophilus) decoloratus, and Rhipicephalus (Boophilus) microplus (Ixodida: Ixodidae). Fifteen females and three replicates were tested, incubated at $28 \pm 1{ }^{\circ} \mathrm{C}, 85-95 \% \mathrm{RH}, 12: 12 \mathrm{~L}: \mathrm{D}$, and were monitored daily. C. anisata caused $100 \%$ mortality in all engorged females and its $1 / 8$ 
dilution destroyed $100 \%$ of eggs laid by $A$. variegatum. Palm kernel vegetable oil caused $100 \%$ mortality in female species of the genus Rhipicephalus (B.). Flumethrin was very toxic to ticks. Since Palm kernel vegetable oil has a significant toxicity, the two oils tested can be an alternative control of the studied ticks after additional studies.

Keywords: Cattle, ticks, reproductive capacity, Clausena anisata, topical test

\section{Introduction}

Togo is a West African country. Its Maritime Region where the capital Lomé is located is home to almost half of the country's population (42\%) (DGSCN, 2013) with a growing demand for meat products. The Maritime region enjoys a Guinean tropical climate marked by a reduction in rainfall. This climate supports vegetation characterized by the presence of natural or artificial forest islands with green grassy areas in between (Kokou, 2000) all year round. The herbs feed livestock. In addition, this region is irrigated by a regular river system reinforced by a vast system of natural and artificial ponds which provide water for cattle breeding. These assets ensure the breeding of livestock, especially cattle which are increasingly important in Togo (Kulo, Assogba, Pitala, \& Poutouli, 2012), but also attracting transhumance. Despite this potential, cattle numbers are nationally estimated at 446183 of which only 22512 are in the Maritime Region (DEP, 2016). Breeding in this region is confronted with a reduction of grazing areas (Kamana, 2012), and most especially a proliferation of ticks. However, three tick species, Amblyomma variegatum, Rhipicephalus (Boophilus) decoloratus and Rhipicephalus (Boophilus) microplus (Ixodida: Ixodidae), characterize this region (Mollong, Nuto, Bawa, \& Amevoin, 2018).

The tick problem becomes recurrent when animals are forced to stay on the same pastures for long periods (Kulo et al., 2012) in coexistence with transhumants. Indeed, Ixodidae ticks are by far economically the most important external parasites and it threatens $80 \%$ of the global cattle population (Ghosh, Azhahinambia, \& Yadav, 2007). Their infestations cause weight loss and skin damage in animals (Farougou, Adakal, \& Boko, 2013; Stachurski, 2007). This significantly reduces the quality and quantity of meat and milk production. Pathogens and diseases transmitted by ticks also increase mortality and destroy most of the effort of small cattle farms (Nejash, 2016; Walker, 2014). Direct economic losses are therefore related to ticks range from $\$ 13.9$ to $\$ 18.7$ billion / year (Ghosh et al., 2007). In addition, there are indirect losses associated with treatment costs and clinical cases (Walker, 2014; Vial, 2008 ) that add to the already negative impact of ticks. In addition, despite the multiple means of struggle against the ticks, we observe the development of resistance phenomena against chemical acaricides (Abbas, Zaman, Colwell, 
Gilleard, \& Iqbal, 2014; Lovis et al., 2012). We also note the problems of bioaccumulation of residues of these chemical acaricides in animal tissues and milk and their transfer across food chains, as well as ecological, environmental, and public health issues (De Meneghi, Stachurski, \& Adakal, 2016). Chemical laboratories struggle to find new molecules for the rational control of these parasites, especially for $R h$. (B.) microplus. This new invasive tick from West Africa has become resistant to all classes of chemical miticides (Abbas et al., 2014; Adakal et al., 2013). It has great ecological adaptability and is able to displace native species of the same genus (Boka et al., 2017; Biguezoton et al., 2016; De Clercq et al., 2015; Boka, Madder, Achi, Kaboret, \& Berkvens, 2014; Madder, Adehan, De Deken, Adehan, \& Lokossou, 2012). Nowadays, the use of plant extracts with acaricide properties, as new control methods, is being explored to cope with tick threats (Pazinato et al., 2016; Yessinou et al., 2016; Chagas et al., 2014), although their essential oils are volatile.

Furthermore, this study was conducted based on the context of the search for effective and long-term management of ticks using the available biodegradable local plant materials that are cheaper and less harmful to breeders, consumers, and the environment. The objective was to evaluate, in the laboratory, the effect of Clausena anisata (Willd) Hook. (Rutaceae) essential oil and palm kernel oil and their mixtures on the survival and reproductive capacity of engorged females of the three characteristic cattle tick species in the Maritime Region of Togo.

\section{Materials and Methods \\ The Products Tested \\ Essential Oil of $C$. anisata}

The essential oil was supplied by the Laboratory of Natural Plant Extracts and Aromas (LEVAN) of the University of Lomé. A sample of this essential oil was analyzed by Gas Chromatography (C.P.G.) and by Mass Spectrometry (C.P.G./S.M.) at SARL PYRENESSENCES ANALYZES - 2, chemin de la Plaine - 11340 Belcaire, France.

\section{Palm Kernel Vegetable Oil}

It is the virgin vegetable oil of palm kernel used in the preparation of dietary fat, and for the manufacture of soaps and several cosmetics. This oil was purchased from a supplier who obtained it by squeezing crushed and steamed seeds for 15 to 20 minutes. Outtara, Meite, Dally, and Kati-Coulibaly (2016) showed that this oil was composed mainly of lauric, myristic, oleic, and palmitic acids at more than $88 \%$. 


\section{Flumethrin}

The chemical acaricide used was FLUMAX manufactured by ASHISH LIFE SCIENCE PVT LIMITED 213, Laxmi Plaza, New Link Road, Andheri (W), Mumbai-53, India. It is composed of flumethrin $1 \%(\mathrm{~m} / \mathrm{v})$ and belongs to the class of synthetic pyrethroids. We have used it as a reference acaricide to assess the toxicity of the essential oil of $C$. anisata.

\section{The Dilutions Tested}

The crude extracts of essential oil and vegetable oil as well as $1 \%$ flumethrin were tested on engorged females of ticks' species. Then, the crude extract of $C$. anisata was diluted by cascading in virgin palm kernel vegetable oil (v/v) to give mixtures with concentrations $0.5,0.25$ and 0.125 which were applied to the engorged females. Flumethrin dilutions were made in the same way.

\section{Collection and Preparation of Ticks for Experiments}

The engorged females of the different species were collected from cattle on the Experimental Agricultural Station of the Graduate School of Agronomy of the University of Lomé between 6 am and 8 am before the animals leave for grazing. After restraining each animal, a "tire-tique" was used to remove the ticks. For good aeration, boxes with $1 \mathrm{~mm}$ diameter perforations were used to transport the ticks to the Laboratory of Applied Entomology (LAE). The ticks were first washed with distilled water, wiped with towel paper, and then thoroughly examined to ensure that they are in good condition for egg laying. A morpho-anatomical identification key of Ixodidae by Walker et al. (2014) was used to identify ticks. A very sensitive balance (SARTORIUS GMBH GÖTTINGEN type PT120) was used to weigh them. Engorged females of $A$. variegatum reserved for testing weighed between $2000-4000 \mathrm{mg}$, while those of $R h(B)$ decoloratus and $R h$ (B) microplus weighed between $150-350 \mathrm{mg}$. They were incubated at $28 \pm 1{ }^{\circ} \mathrm{C}, 80-95 \%$ relative humidity $(\mathrm{RH})$, and 12:12 L:D approsimative photoperiod. These conditions were checked every day by means of a thermo-hygrometer (type: TROTEC BZ05) to monitor the environment. Thus, the experiments were performed on the day of collection.

\section{Evaluation of Some Biological Parameters of Tick Females}

To evaluate the duration of pre-oviposition, oviposition, embryogenesis, number of eggs laid and hatching rates, according to FAO (2004), fifteen (15) females of each species were tested. Taking into account the tick weight, a drop of $75 \mu \mathrm{L}$ of distilled water was deposited on the back of each engorged female of the $A$. variegatum species and $5 \mu \mathrm{L}$ on that of each engorged female of $R h$. (B.) decoloratus and $R h$. (B.) microplus species using 
a $25 \mu \mathrm{L}$ Drummond micropipette to evaluate the effect of control. Monitoring was done daily and eggs were counted. Incubation was at $28 \pm 1{ }^{\circ} \mathrm{C}, 80-95 \%$ RH, and 12: 12 L:D. One hundred (100) eggs of each species were used to evaluate hatch rates based on five replicates.

\section{Topical Tests with Crude Extracts and Dilutions}

Fifteen (15) engorged females of each tick species were deposited in a spawning box. As before, a drop of $75 \mu \mathrm{L}$ of crude extract of essential oil of C. anisata and palm kernel vegetable oil, flumethrin (1\%), and their serial dilutions $(\mathrm{v} / \mathrm{v})$ were deposited on the back of each engorged female of the species of $A$. variegatum, and $5 \mu \mathrm{L}$ on that of each engorged female of $R h$. (B.) decoloratus and Rh. (B.) microplus species using a Drummond micropipette. After 6 hours, each engorged female was removed from the box to avoid permanent contact with the excess product and it was deposited on a paper towel to dry, and then transferred to a new spawning box. They were incubated separately at a temperature of $28 \pm 1{ }^{\circ} \mathrm{C}$, at $80-95 \% \mathrm{RH}$ for $12 \mathrm{~L}: 12 \mathrm{D}$. Three replicates were made and survival was checked daily. The period of preoviposition, oviposition, and eggs laid were recorded. In addition, possible egg hatching and embryogenesis in case of egg laying were observed. The effectiveness of the oils was evaluated in comparison with flumethrin, the reference acaricide. the formula:

Natural mortality of ticks' species was determined in the controls by

$$
\text { Natural mortality }(\%)=\frac{\text { Number of dead females }}{\text { Total number of females }} \times 100
$$

In tests where witness mortalities exceed $5 \%$ or more, Abbott's (1925) formula was used to calculate corrected mortality:

$$
\text { Corrected mortality }(\%)=\frac{(\%) \text { Mortality in the test }-(\%) \text { Natural mortality }}{100 \%-(\%) \text { Natural mortality }} \times 100
$$

\section{Monitoring of Eggs Laid by Tested Females}

Eggs laid by the treated females were monitored. During eggs laying, some of them were collected at the end of the day and transferred to new boxes. Eggs from all boxes were monitored for embryogenesis and/or hatching. Toxicity was evaluated at the following points: destruction of eggs, duration of embryogenesis, and especially the non hatching of the eggs. All these observations were made with a binocular microscope type Nikon SMZ 745.

\section{Data Analysis}

Statistical processing of the data was performed using an analysis of variance (ANOVA) at the 5\% threshold with SPSS.v.16.0 software. The 
averages of weight, phase times, diapers, and female mortalities were discriminated with the LSD test, using the same software.

\section{Results}

\section{Composition of the Essential Oil of the Leaves of C. Anisata}

The analysis of this essential oil showed that estragol (57.06\%) and transanethole (29.88\%) were the major compounds, constituting $86.94 \%$ of crude extract. Other compounds exceeding $1 \%$ are anisaldehyde $(2.67 \%)$, p-cymene $(2.31 \%)$, and $\alpha$-pinene (1.07\%).

\section{Estimated Biological Parameters in Females of Different Species}

Monitoring engorged females of each tick species showed a clear difference between the characteristics of monophasic ticks of the genus Rhipicephalus (B.) and those of triphasic ticks of the genus Amblyomma (Table 1).

Table 1. Mean values of the parameters studied in females of the three tick species at $28 \pm 1$ ${ }^{\circ} \mathrm{C}, 80-95 \% \mathrm{RH}$, and 12L: 12D. (Number $=15$ females)

\begin{tabular}{|c|c|c|c|c|c|c|}
\hline Species & $\begin{array}{c}\text { Weight } \\
(\mathbf{m g} \pm \mathbf{S D})^{*}\end{array}$ & $\begin{array}{c}\text { Pre-oviposition } \\
\text { period } \\
\text { (days } \pm \text { SD)* }^{\text {(day }}\end{array}$ & $\begin{array}{c}\text { Oviposition } \\
\text { period } \\
(\text { days } \pm \text { SD)* }\end{array}$ & $\begin{array}{c}\text { Eggs laid } \\
(\text { Number } \pm \text { SD)* }\end{array}$ & $\begin{array}{c}\text { Incubation } \\
\text { period } \\
(\text { days } \pm \text { SD })^{*}\end{array}$ & $\begin{array}{l}\text { Hatching } \\
(\% \pm \text { SD)* }\end{array}$ \\
\hline A. variegatum & $3060.70 \pm 449.65^{\mathrm{a}}$ & $12 \pm 1.52^{\mathrm{a}}$ & $33.93 \pm 3.99^{a}$ & $15350 \pm 3650.01^{\mathrm{a}}$ & $53.73 \pm 2.89^{a}$ & $94.4 \pm 4.21^{\mathrm{a}}$ \\
\hline Rh. (B.) decoloratus & $266.67 \pm 43.69^{b}$ & $4.4 \pm 0.63^{b}$ & $11.13 \pm 1.64^{\mathrm{b}}$ & $2317.6 \pm 613.41^{\mathrm{b}}$ & $27.4 \pm 2.58^{b}$ & $89.4 \pm 2.19^{a}$ \\
\hline Rh. (B.) microplus & $233.33 \pm 48.2^{b}$ & $4.13 \pm 0.63^{b}$ & $10.93 \pm 1.75^{\mathrm{b}}$ & $2632.2 \pm 485.27^{\mathrm{b}}$ & $24.73 \pm 1.22^{c}$ & $91,8 \pm 3,42^{\mathrm{a}}$ \\
\hline Statistical test & $\begin{array}{c}\mathrm{F}_{(44, \text { error })}= \\
574.106 ; \\
\mathrm{P}<0.0001\end{array}$ & $\begin{array}{c}\mathrm{F}_{(44, \text { error })}= \\
377.104 ; \\
\mathrm{P}<0.0001\end{array}$ & $\begin{array}{c}\mathrm{F}_{(44, \text { error })}= \\
362.755 ; \\
\mathrm{P}<0.0001\end{array}$ & $\begin{array}{c}\mathrm{F}_{(44, \text { error })}= \\
178.148 \\
\mathrm{P}<0.0001\end{array}$ & $\begin{array}{c}\mathrm{F}_{(44, \text { error })}= \\
699.294 ; \\
\mathrm{P}<0.0001\end{array}$ & $\begin{array}{c}\mathrm{F}_{(14, \text { error })}= \\
2.735 ; \\
\mathrm{P}<0.105\end{array}$ \\
\hline
\end{tabular}

* Means with the same letter in the same column are not significantly different (ANOVA followed by LSD test, $\mathrm{P}<0.05$ ).

Indeed, female $A$. variegatum weighed on average $3060.70 \pm 449.65$ $\mathrm{mg}$, while those of $R h$. (B.) decoloratus and $R h$. (B.) microplus weighed on average 266, $67 \pm 43.69 \mathrm{mg}$ and $233.33 \pm 48.2 \mathrm{mg}$, respectively (Table 1$)$. The average time that elapsed from the collection of engorged females to the start of egg laying (Pre-oviposition period) was $12 \pm 1.52$ days for $A$. variegatum, $4.4 \pm 0.63$ days for $R h$ (B.) decoloratus, and $4.13 \pm 0.63$ days for $R h(B)$ microplus. A. variegatum, the triphasic tick, had a longer pre-oviposition period than the monophasic ticks, $R h(B)$ decoloratus and $R h(B)$ microplus. In addition, mean egg laying time was $33.93 \pm 3.99$ days, $11.13 \pm 1.64$ days, and $10.93 \pm 1.75$ days for $A$. variegatum, $R h$. (B.) decoloratus and $R h$. (B.) microplus respectively. On average, $15350 \pm 3650.01$ eggs were laid by $A$. variegatum, while $R h$. (B.) decoloratus and $R h$. (B.) microplus averaged $2317.6 \pm 613.41$ eggs and 2632.2 \pm 485.27 eggs during the laying period. The mean incubation time of eggs was $53.73 \pm 2.89$ days in $A$. variegatum, $27.4 \pm$ 2.58 days in $R h$. (B.) decoloratus, and $24.73 \pm 1.22$ days in $R h$. (B.) microplus. 
Statistical comparison of the means of these parameters showed significant differences between $A$. variegatum and $R h$. (B.) decoloratus and Rh. (B.) microplus (Table 1). Only mean hatching rates did not show a significant difference $\left(\mathrm{F}_{(14, \text { Error })}=2.735, \mathrm{P}<0.105\right)$ and were $94.4 \%, 89.4 \%$ and $91.8 \%$ respectively for $A$. variegatum, $R h$. (B.) decoloratus, and $R h$. (B.) microplus. Hatching was simultaneous, producing a large number of larvae for each of the three species. After hatching, the very soft and fragile larvae remain grouped in clusters and harden through digesting their vitellus. Two weeks after hatching, they are ready to go in search of a host for a blood meal.

\section{Effect of Crude Extracts on Engorged Females}

The deposition of $75 \mu \mathrm{L}$ of palm kernel oil on the dorsal part of $A$. variegatum females showed that they had normal movements as those of the controls. The results of the tests with this oil were similar to those for females tested with distilled water. This oil was therefore non-toxic. In contrast, the deposition of a drop of $5 \mu \mathrm{L}$ of the vegetable oil on the backs of engorged females of $R h$. (B.) decoloratus and $R h$. (B.) microplus species was toxic since all were dehydrated and died after 48 hours. No egg laying is observed (Table 2 ). On the other hand, tests with the crude essential oil of $C$. anisata showed abnormal movement of the females especially in the species $A$. variegatum. This oil proved to be toxic to all the engorged females of the different species of tick tested, since they all died after 48 hours. They were dehydrated after 4 or 5 days and all look the same (Photo 1). The globular body of these parasites shrivels with ripples and wrinkles. The same observations were made with flumethrin, the reference acaricide.

Table 2. Mortality of engorged females tested with crude extracts compared to flumethrin.

(Number $=15$ females)

\begin{tabular}{|c|c|c|c|c|c|c|c|c|c|}
\hline \multirow{2}{*}{$\begin{array}{c}\text { Crude } \\
\text { Extracts/ } \\
\text { flumethrin } \\
\end{array}$} & \multirow{2}{*}{ Species } & \multirow{2}{*}{$\begin{array}{c}\text { Weight } \\
(\mathrm{mg} \pm \mathrm{SD})^{*}\end{array}$} & \multicolumn{2}{|c|}{ Number of ticks } & \multicolumn{3}{|c|}{ Eggs laying } & \multirow{2}{*}{$\begin{array}{c}\text { Mean number } \\
\text { of eggs } \\
\text { laid }\end{array}$} & \multirow{2}{*}{$\begin{array}{c}\text { Hatching } \\
(\%)\end{array}$} \\
\hline & & & Alive & Dead & Comp & Part & Abs & & \\
\hline \multirow{3}{*}{$\begin{array}{c}\text { Palm kernel } \\
\text { vegetable } \\
\text { oil }\end{array}$} & A. variegatum & $2512 \pm 356.39$ & 15 & - & Yes & - & - & $13288 \pm 2528.43$ & $90.4 \pm 6.87$ \\
\hline & Rh. (B.) decoloratus & $233.3 \pm 53.94$ & - & 15 & - & - & - & - & - \\
\hline & Rh.(B.) microplus & $205.33 \pm 41.55$ & - & 15 & - & - & - & - & - \\
\hline $\begin{array}{c}\text { Clausena } \\
\text { anisata }\end{array}$ & Rh. (B.) microplus & $215.33 \pm 45.33$ & - & 15 & - & - & - & - & - \\
\hline \multirow[b]{2}{*}{ Flumethrin } & A. variegatum & $2669.3 \pm 441.76$ & - & 15 & - & - & - & - & - \\
\hline & Rh. (B.)decoloratus & $214.67 \pm 50.69$ & - & 15 & - & - & - & - & - \\
\hline
\end{tabular}



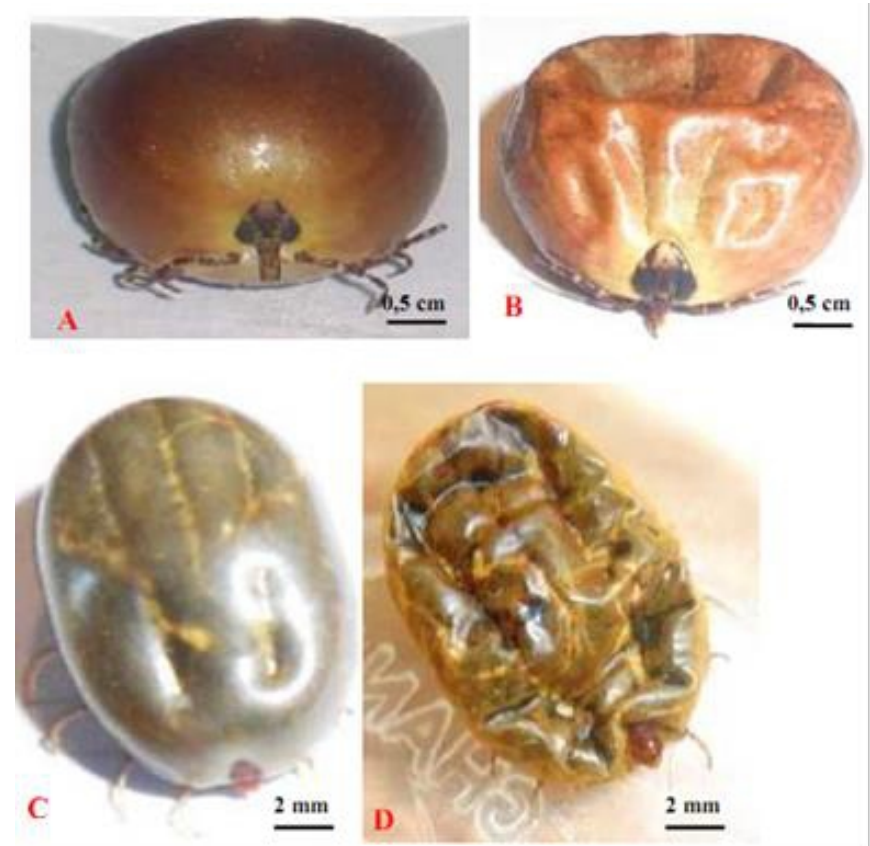

Photo 1. Aspects of the different female tick species tested.

A: A. variegatum control; B: A. variegatum tested with crude essential oil of C. anisata; C: Rh. (B.) microplus control; D: Rh. (B.) microplus tested with vegetable oil of palm kernel

\section{Effects of 1/8, 1/4 and 1/2 Dilutions on Engorged Females of $A$. variegatum}

Topical tests carried out with the different dilutions showed that at the dilution of $1 / 2$ of essential oil, the females of $A$. variegatum die immediately it was tested with crude essential oil (Table 3 ).

In contrast, these females survive and lay eggs when $1 / 4$ and $1 / 8$ dilutions of essential oil are applied (Photo 2). However, some females die during the oviposition period. Their bodies turn black just like the eggs they laid.
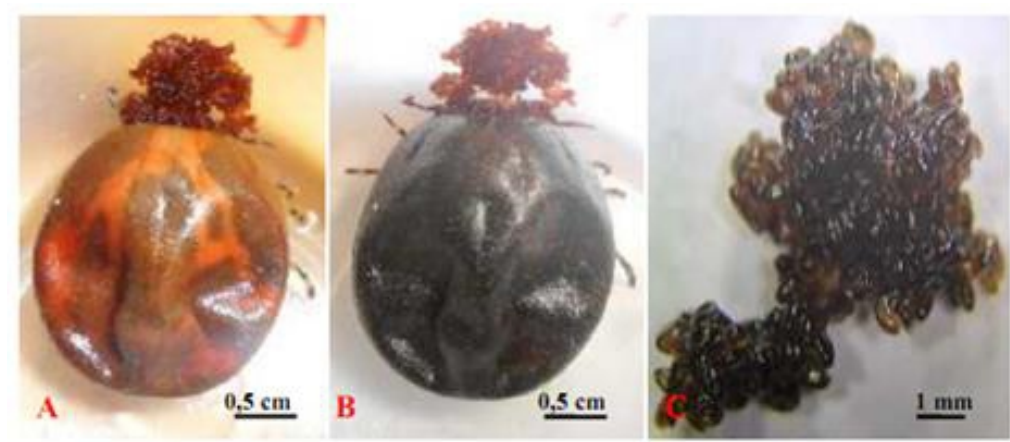

Photo 2. Laying female of $A$. variegatum treated with a $1 / 4$ or $1 / 8$ dilution of essential oil.

A: early laying female; B: dead female; $\mathbf{C}$ : eggs 
Table 3. Effects of the different dilutions on the females of $A$. variegatum at $28 \pm 1^{\circ} \mathrm{C}, 80-$ 95\% RH and 12L: 12D. (Number $=15$ )

\begin{tabular}{|c|c|c|c|c|c|c|c|c|c|}
\hline \multirow{2}{*}{$\begin{array}{c}\text { Crude } \\
\text { Products or } \\
\text { chemical } \\
\end{array}$} & \multirow{2}{*}{$\begin{array}{c}\text { Dilutions } \\
\text { tested }\end{array}$} & \multirow{2}{*}{$\begin{array}{c}\text { Weight } \\
(\mathbf{m g} \pm \mathbf{S D})^{*}\end{array}$} & \multicolumn{2}{|c|}{ Number of ticks } & \multicolumn{3}{|c|}{ Laying } & \multirow{2}{*}{$\begin{array}{l}\text { Number of } \\
\text { eggs laid }\end{array}$} & \multirow{2}{*}{ 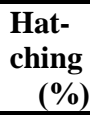 } \\
\hline & & & Alive & Dead & Comp & Part & Abs & & \\
\hline \multirow{3}{*}{ C. anisata } & $(1 / 2)$ & $2574.7 \pm 336.62$ & - & 15 & - & - & - & - & - \\
\hline & $(1 / 4)$ & $2467.3 \pm 285.09$ & 15 & - & - & Yes & - & $7054.6 \pm 2158.98^{b}$ & No \\
\hline & $(1 / 8)$ & $2554.7 \pm 312.13$ & 15 & - & - & Yes & - & $3362.87 \pm 1272.52^{\mathrm{c}}$ & No \\
\hline \multirow{3}{*}{ Flumethrin } & $(1 / 2)$ & - & - & - & - & - & - & - & - \\
\hline & $(1 / 4)$ & $2612.7 \pm 309.9$ & - & 15 & - & - & - & - & - \\
\hline & $(1 / 8)$ & $2412 \pm 220.75$ & - & 15 & - & - & - & - & - \\
\hline
\end{tabular}

Comp $=$ complete $;$ Part $=$ partial; Abs $=$ absent

Flumethrin is very toxic to female $A$. variegatum. The dilution of $1 / 8$ induced the death of all engorged females. In these conditions, no egg laying was recorded. These observations indicate that flumethrin is more toxic than the essential oil of $C$. anisata.

Monitoring females of $A$. variegatum tested at $1 / 4$ and $1 / 8$ dilutions of $C$. anisata showed that the period of pre-oviposition and oviposition was dose-dependent (Table 4). The pre-oviposition period was longer (one week or more) than in control. In contrast, the oviposition period was shorter than in the control. The number of eggs laid was reduced and some females die during the oviposition period (Photo 2B) and the eggs laid at the beginning are not viable. Hence, they became black (Photo $2 \mathrm{C}$ ).

Table 4. Effects of $1 / 8$ and $1 / 4$ dilutions of C. anisata on certain biological parameters of $A$. variegatum females. (Number $=15$ )

\begin{tabular}{|c|c|c|c|c|c|c|}
\hline Tests & $\begin{array}{c}\text { Weight } \\
(\mathbf{m g} \pm \mathrm{SD})^{*}\end{array}$ & $\begin{array}{c}\text { Pre-oviposition } \\
\text { period } \\
\text { (days } \pm \text { SD)* }\end{array}$ & $\begin{array}{c}\text { Oviposition } \\
\text { period } \\
(\text { days } \pm \text { SD) }\end{array}$ & $\begin{array}{c}\text { Eggs laid } \\
(\text { Number } \pm \mathrm{SD}) *\end{array}$ & $\begin{array}{c}\text { Incubation } \\
\text { period } \\
\text { (days } \pm \text { SD)* }\end{array}$ & $\begin{array}{r}\text { Hatching } \\
(\% \pm \text { SD })^{*}\end{array}$ \\
\hline $\begin{array}{l}\text { Palm kernel } \\
\text { oil }\end{array}$ & $2512 \pm 356.39^{a}$ & $11.33 \pm 2.02^{\mathrm{a}}$ & $30.67 \pm 2.35^{\mathrm{a}}$ & $13288 \pm 2528.43^{a}$ & $55.73 \pm 3.26^{\mathrm{a}}$ & $90.4 \pm 6.87^{\mathrm{a}}$ \\
\hline $\begin{array}{l}\text { Dilution } \\
(1 / 8) \text { of } C \text {. } \\
\text { anisata }\end{array}$ & $2554.7 \pm 312.13^{b}$ & $16.6 \pm 3.37^{b}$ & $17 \pm 3.18^{b}$ & $7054.6 \pm 2158.98^{b}$ & - & - \\
\hline $\begin{array}{l}\text { Dilution } \\
(1 / 4) \text { of } C \text {. } \\
\text { anisata }\end{array}$ & $2467.3 \pm 285.09^{b}$ & $19.13 \pm 3.09^{c}$ & $8 \pm 2.53^{c}$ & $\begin{array}{c}3362,87 \pm \\
1272.52^{c}\end{array}$ & - & - \\
\hline $\begin{array}{l}\text { Statistical } \\
\text { Test }\end{array}$ & $\begin{array}{c}\mathrm{F}_{(44, \text { error })}=12.124 \\
\mathrm{P}<0.0001\end{array}$ & $\begin{array}{c}\mathrm{F}_{(44, \text { error })}= \\
26.126 ; \mathrm{P}<0.000\end{array}$ & $\begin{array}{c}\mathrm{F}_{(44, \text { error })}= \\
265.291 ; \\
\mathrm{P}<0.000\end{array}$ & $\begin{array}{c}\mathrm{F}_{(44, \text { error })}=89.350 \\
; \\
\mathrm{P}<0.000\end{array}$ & & \\
\hline
\end{tabular}

* Averages with the same letter in the same column are not significantly different (ANOVA followed LSD test, P <0.05) 


\section{Monitoring of Eggs laid by Treated Females}

Eggs laid by females $A$. variegatum at the $1 / 4$ dilution were all affected. This occurs whether they were transferred to new boxes after laying or not. The eggs were completely emptied of their contents and blackened (Photo 3B).

In addition, among eggs laid by females $A$. variegatum treated with the essential oil diluted $1 / 8$ and transferred to new boxes, some eggs showed the onset of embryogenesis (Photo 3C) that ultimately failed. This rough embryogenesis, although characterized by a white spot that appears in each egg, shows that the eggs have been completely emptied of their contents. This excludes any egg evolution. The essential oil has been effective on eggs and their evolution due to treatment of females.

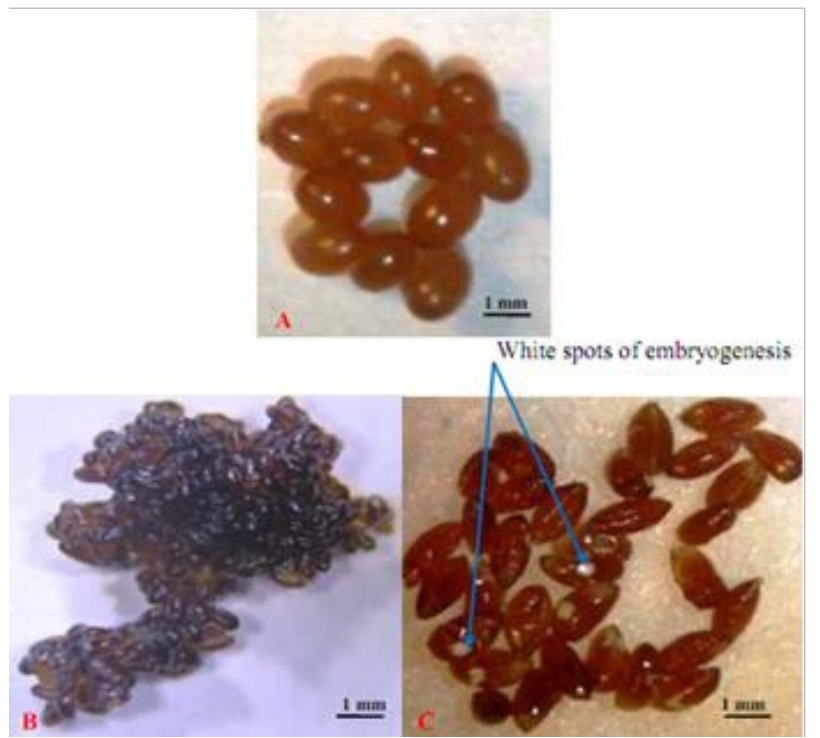

Photo 3. Different aspects of the eggs laid in control and treated females. $(\times 40)$

A: healthy eggs laid by a female in control; B: blackened eggs laid by a female treated at a dilution of $1 / 4$; $\mathbf{C}$ : eggs with the onset of embryogenesis laid by female treated at a dilution of $1 / 8$.

\section{Discussion}

Climatic conditions are one of the most important factors governing the reproductive capacity of female ticks. They influence the different phases of development cycles in nature and livestock. These conditions contribute greatly to egg-laying and hatching, which makes it possible to perpetuate the species through infestations and the number of generations. Yonow (1995) showed that at temperatures below $15^{\circ} \mathrm{C}$ or above $40^{\circ} \mathrm{C}$ with a relative humidity ranging between $45-97 \%$, there was no egg laid. The conditions of these experiments, $28 \pm 1{ }^{\circ} \mathrm{C}, 80-95 \% \mathrm{RH}$ and $12: 12 \mathrm{~L}: \mathrm{D}$, are therefore favorable for the development of the ticks studied as corroborated by some 
authors (Boka et al., 2014; Bowessidjaou, 1991) on A. variegatum, Rh. (B.) decoloratus, and Rh. (B.) microplus. This explains the presence of these species all year round in a Guinean tropical climate (Mollong et al., 2018) justifying the need for prophylactic measures.

With respect to the laboratory toxicity tests, they revealed that palm kernel vegetable oil is toxic to $R h$. (B.) decoloratus and $R h$. (B.) microplus while it is ineffective on engorged females of $A$. variegatum. This toxicity is probably caused by mechanical and chemical effects of vegetable oil on teguments of these species of ticks. Some authors (Lawson \& Weires, 1991; Butler \& Henneberry, 1990) showed the effectiveness of vegetable oils used with detergents as mixtures against insects and mites. Although the mode of action of vegetable oils remains uncertain, Larew and Locke (1990) suggested that they may drown insects and mites, or facilitate the removal of waxes from their cuticle, physical action, enzymatic inhibition or cell membrane disruption. In our study, the liposolubility and oiliness of the palm kernel oil may soften the integuments which become soft and vulnerable. The primary role of these teguments (cuticle), being to prevent water and air loss (Wigglesworth, 1972), follows dehydration and asphyxiation with drying of the tick. However, effective studies on the integumentary structure of the different species will make it possible to elucidate the survival and death of ticks. Also, palm kernel vegetable oil which is composed of more than $88 \%$ lauric, myristic, oleic and palmitic acids (Outtara et al., 2016) and which is widely used for cooking, and for skin and hair care, must have acaricidal effect.

In this study, we observed that $C$. anisata essential oil caused the drying and death of engorged female ticks. Nuto, Amevoin, Koumaglo and Glitho (2008) have already tested the repellency and toxicity of this oil on flies and ticks with more than $90 \%$ mortality after a topical test on ticks with crude extract on sheep. C. anisata essential oil must have the same effects outlined above (Larew \& Locke, 1990). Also, it may even alter the cuticle more quickly than vegetable oils. Although the mechanisms of action of essential oils of $C$. anisata are unknown and relatively studied little, the studies of Chiasson and Beloin (2007) and Chiasson, Bostanian and Vincent (2004 a and b) showed that chitin, which is the essential component of the arthropod cuticle, was the target of the essential oils which act directly on the mites cuticle and rapidly penetrate their bodies. Under these circumstances, the trachea and air sacs of ticks coated with this waxy layer are affected by the essential oil which can lead to asphyxiation. Essential oil of $C$. anisata would have the same properties and was able to partially or totally inhibit pré-oviposition, oviposition, eggs laid, hatching and therefore, reduce A. variegatum reproductive efficiency. Several authors (Pazinato et al., 2016; Yessinou et al., 2016) have made the same observations with most other essential oil from 
plants and have highlighted that their effectiveness is due to monoterpenoids which are the major compounds. This has been confirmed by Gazim et al. (2011) who showed that monoterpenoids compounds of essential oils had effects on the growth, moulting, fecundity, and development of insects and mites. Although our essential oil is low in monoterpenoids compounds ( $\mathrm{p}$ cymene $2.31 \%$ and $\alpha$-pinene $1.07 \%$ ), estragole $(57.06 \%)$ and trans-anethole $(29.88 \%)$ which are phenylpropenes were its major compounds. These compounds could be the cause of the effectiveness of essential oil of $C$. anisata. Indeed, Okunade and Olaifa (1987) showed that estragole, which is the major component of the fresh leaf essential oil of C. anisata, is 1.5 times more toxic than the crude extract. In short, the desiccation observed in engorge female tick is probably related to dehydration and asphyxiation following physical alteration of the cuticle in general. However, the precise determination of the site (s) of degradation of the outer envelope of the ticks and the type of damage caused by the topical application remains to be verified by electron microscopy in order to specify the effect of the essential oil on specific parts of the tick. This is what Domingues et al. (2013) meant when they noted that knowing the composition of the tick cuticle is critical in the formulation of the constituents of plant extracts with solvents in the fight against ticks. Not surprisingly, researchers are mixing essential oils to increase their effectiveness (Vinturelle et al., 2017; Yessinou et al., 2016). Indeed, the death of $A$. variegatum engorged females has been dose-dependent since they survive and lay eggs when the essential oil of $C$. anisata dose drops. These results were observed by Pazinato et al. (2016) and dos Santos, Vogel and Monteiro (2012) who additionally note the inhibition of oviposition and hatching as a function of dose. The decrease in toxicity of the essential oil of $C$. anisata is caused by the decrease in the amount of essential oil in the various dilutions on the one hand; this greatly reduces cuticle alteration by the essential oil (Chiasson \& Beloin, 2007; Chiasson et al., 2004 a and b) and consequently slows down the diffusion of the essential oil, which probably can no longer effectively damage the cuticle. On the other hand, the rapid decline in toxicity can be explained by the volatility of the essential oil. Thus, this reduces its time of persistence on ticks by loss of both major and minor compounds which are responsible for mortality. Indeed, essential oil of $C$. anisata which alter the cuticle of the tick not only exposes it to climatic conditions, but above all, it can diffuse and damage the internal structures of ticks indispensable for vitellogenesis and oviposition and/or the physicochemical changes in the quality of the hemolymph. This impacts the survival and reproductive capacity of ticks. This result was observed by Roma, Furquim, Bechara and Camargo-Mathias (2010) after using permethrin on the semi-engorged female of Rhipicephalus sanguineus (Ixodida: Ixodidae). A similar result is corroborated by de Sousa, Rocha, Saboia-Morais and Borges 
(2013) on Rh. (B.) microplus using Melia azedarach (Meliaceae) essential oil. This results in partial inhibition of oviposition, destruction of eggs laid, and inhibition of hatching as we miss it with the essential oil of $C$. anisata. At present, aqueous extracts and essential oils from thousands of plants continue to be tested to find an alternative to tick resistance, but also to environmental pollution and bioaccumulation of synthetic acaricides as well as their transmission through the food chain.

\section{Conclusion}

This study showed that the essential oil of $C$. anisata was toxic to the three tick species of cattle: $A$. variegatum, $R h$. (B.) decoloratus, and $R h$. (B.) microplus. The palm kernel vegetable oil used as a solvent was very toxic to Rhipicephalus (B.) species, in particular Rh. (B.) microplus, which spreads very rapidly in West Africa and has become resistant to several classes of synthetic acaricides. Control of ticks based on plant extracts tested has proven effective and is a promising alternative for combating tick resistance.

\section{Acknowledgments}

The authors would like to express their thanks to Dr. Abalo E. Kulo (Director of the Experimental Agricultural Station of the Graduate School of Agronomy, University of Lomé) for having authorized tick collection, and Dr Tetevi Wilson-Bahun for helping in producing the English version of the manuscript.

\section{References:}

1. Abbas, R. Z., Zaman, M. A., Colwell, D. D., Gilleard, J., \& Iqbal, Z. (2014). Acaricide resistance in cattle ticks and approaches to its management: The state of play. Vet. Parasitol. 203: 6-20. http://dx.doi.org/10.1016/j.vetpar.2014.03.006

2. Abott, W. S. (1925). A method of computing the effectiveness of an insecticide. J. Econ. Entomol. 18: 265-267.

https://doi.org/10.1093/jee/18.2.265a

3. Adakal, H., Biguezoton, A., Zoungrana, S., Courtin, F., De Clercq, E. M., \& Madder, M. (2013). Alarming spread of the Asian cattle tick Rhipicephalus microplus in West Africa: another three countries are affected: Burkina Faso, Mali and Togo. Exp. Appl. Acarol. 61: 383-386. https://doi.org/10.1007/s 10493-013-9706-6

4. Biguezoton, A., Chevillon, C., Adehan, S., Adakal, H., Zoungrana, S., \& Farougou, S. (2016). Community structure, seasonal variations and interactions between native and invasive cattle tick species in Benin and Burkina Faso. Parasites \& Vectors 9 (43): 1-16. 
https://doi.org/10.1186/s13071-016-1305-Z

5. Boka, O. M, Achi, L., Adakal, H., Azokou, A., Yao, P., Yapi, Y. G., Kone, M., Dagnogo, K., \& Kaboret, Y. Y. (2017). Review of cattle ticks (Acari, Ixodida) in Ivory Coast and geographic distribution of Rhipicephalus (Boophilus) microplus, an emerging tick in West Africa. Exp. Appl. Acarol. 71(4): 355-369.

https://doi org/10.1007/s10493-017-0129-7

6. Boka, O. M., Madder, M., Achi, Y. L., Kaboret, Y. Y., \& Berkvens, D. (2014). Modélisation du remplacement de Rhipicephalus (Boophilus) decoloratus par Rhipicephalus (Boophilus) microplus, une tique émergente en Côte d'Ivoire. Euopean Scientific Journal 10(30): 120-132.

7. Bowessidjaou, E. J. (1991). Ticks (ACARINA: IXODOÏDEA) of Togo. Doctorate Thesis, University of Neuchatel-Faculty of Sciences, Institut of Zoology, 151p. French.

8. Butler, G. D., Jr, \& Henneberry, T. J. (1990). Pest control on vegetables and cotton with household cooking oils and liquid detergents. Southwest. Enromol. 15: 123-131.

9. Chagas, A. C., Domingues, L. F., Fantatto, R. R., Giglioti, R., Oliveira, M. C., Oliveira, D. H., Mano, R. A., \& Jacob, R. G. (2014). In vitro and in vivo acaricide action of juvenoid analogs produced from the chemical modification of Cymbopogon spp. and Corymbia citriodora essential oil on the cattle tick Rhipicephalus (Boophilus) microplus. Vet. Parasitol. 205(1-2), 277-284.

https://doi org/10.1016/j.vetpar.2014.06.030.

10. Chiasson, H., \& Beloin, N. (2007). «The essential oils as new biopesticides» Literature review. Bulletin of the Entomological Society of Quebec. Antennae 14(1), 3-6. French.

11. Chiasson, H., Bostanian, N., \& Vincent, C. (2004a). Acaricidal properties of a Chenopodium-based biopesticide. J. Econ. Entomol., 97 : 1373-1377.

https://doi.org/10.1603/0022-0493-97.4.1373

12. Chiasson, H., Vincent, C., \& bostanian, N. (2004b). Insecticidal properties of a Chenopodium-based biopesticide. J. Econ. Entomol., $97: 1378-1383$.

https://doi.org/10.1603/0022-0493-97.4.1378

13. De Clercq, E. M., Later, S., Estrada-Peña, A., Madder, M., Adehan, S., \& Vanwambeke, S. O. (2015). Species distribution modelling for Rhipicephalus microplus (Acari: Ixodidae) in Benin, West Africa: Comparing datasets and modelling algorithms. Preventive Veterinary Medicine 118: 8-21.

14. De Meneghi, D., Stachurski, F., \& Adakal, H. (2016). Experience in 
Tick Control by Acaricide in the Traditional Cattle Sector in Zambia and Burkina Faso: Possible Environmental and Public Health Implications. Frontiers in Public Health 4 (239): 1- 11.

https://doi.org/10.3389/fpubh.2016.00239

15. DEP (2016). Direction de l'Elevage et de la Pêche (Lomé-TOGO).

16. de Sousa, L. A. D., Rocha, T. L., Sabóia-Morais, S. M. T., \& Borges, L. M. F. (2013). Ovary histology and quantification of hemolymph proteins of Rhipicephalus (Boophilus) microplus treated with Melia azedarach. Rev. Bras. Parasitol. Vet. 22(3): 339-345. http://dx.doi.org/10.1590/S1984-29612013000300004

17. DGSCN (2013). Le quatrième recensement général de la population et du logement.

Novembre 2010. Rapport final, volume spécial, Lomé-Togo.

18. Domingues, L. F., Giglioti, R., Feitosa, K. A., Fantatto, R. R., Rabelo, M. D., Oliveira, M. C., Oliveira, G. P., Bechara, G. H., \& Chagas, A. C. (2013). Activité in vitro d'extraits d'ananas (Ananas comosus, Bromeliaceae) sur Rhipicephalus (Boophilus) microplus (Acari: Ixodidae). Exp. Parasitol. 134(3): 400-4.

19. dos Santos, F. C. C., Vogel, F. S. F., \& Monteiro, S. G. (2012). Essential basil oil effect (Ocimum basilicum L.) on cattle tick Rhipicephalus (Boophilus) microplus in vitro experiments. Semina: Ciencias Agrarias 33(3): 1133-1140.

DOI: $10.5433 / 1679-0359.2012 \mathrm{v} 33 \mathrm{n} 3 \mathrm{p} 1133$

20. FAO (2004). Resistance management and integrated parasite control in ruminants: Guidelines. Module 1. Ticks: Acaricide resistance: diagnosis, management and prevention, pp. 25-77. www.fao.org/tempref/docrep/fao/010/ag014e/ag014e05.pdf

21. Farougou, S., Adakal, H. \& Boko, C. (2013). Evaluation of the prevalence of cowdriosis in domestic ruminants in Benin. Rev. Méd. Vét. 12: 572-576. French.

22. Gazim, Z. C., Demarchi, I. G., Lonardoni, M. V. C., Amorim, A. C. L., Hovell, A. M. C., $\quad$ Rezende, C. M., Ferreira, G. A., de Lima, E. L., de Cosmo, F. A., \& Cortez, D. A. G. (2011). Acaricidal activity of the essential oil from Tetradenia riparia (Lamiaceae) on the cattle tick Rhipicephalus (Boophilus) microplus (Acari; Ixodidae). Experimental Parasitology 129: 175-178.

doi: 10.1016/j.exppara.2011.06.011

23. Ghosh, S., Azhahianambia, P., \& Yadav, M. P. (2007). Upcoming and future strategies of tick control: a review. J. Vect. Born. Dis. 44: 79-89.

24. Kamana, P. (2012). Socio-economic and environmental Incidences of wildland fires on vegetation in Togo. Memory of DEA 
Environmental Management, FDS, University of Lome, Togo, 53 p. French

25. Kokou, K. (2000). The forest islands of the Togolese coastal plain. Tropical forests Wood 263: 50-56. French

26. Kulo, E. A., Assogba, K., Pitala, W., \& Poutouli, W. (2012). Relationship between the level of infestation of a pastured crop and that of cattle by ticks (Ixodidae) at Lomé, Togo. Rev. Sc. Env. Univ., Lome (Togo), 2012, $n^{\circ}$ 009. ISSN 1812-1403. French

27. Larew, H. G., \& Locke, J. C. (1990). Repellency and toxicity of a horticultural oil against whiteflies on chrysanthemum. HortScience, 25: 1406-1407.

28. Lawson, D. S., \& Weires, R. (1991). Management of European red mite (Acari: $\quad$ Tetranychidae) and several aphid species on apple with petroleum oils and an insecticidal soap. J. Econ. Entomol. 84 (5): 1150-1557.

29. Lovis, L., Guerrero, F. D., Miller, R. J., Bodine, D. M., Betschart, B., \& Sager, H. (2012). Distribution patterns of three sodium channel mutations associated with pyrethroid resistance in Rhipicephalus (Boophilus) microplus populations from North and South America, South Africa and Australia. Int. J. Parasitol. Drug. Resist., 3(2): 216224.

DOI:10.1016/j.ijpddr.2012.08.001

30. Madder, M., Adehan, S., De Deken, R., Adehan, R., \& Lokossou, R. (2012). New foci of Rhipicephalus microplus in West Afr. Exp. Appl. Acarol., 56(4): 385-390.

31. Mollong, E., Nuto, Y., Bawa, R., \& Amevoin, K. (2018). Diversity of cattle ticks, seasonal variation and parasitism in the Maritime Region of Togo. Tropicultura (Trop $\mathrm{n}^{\circ} 3863$ : for bublication). French

32. Nejash, A. (2016). Important Cattle Ticks and Tick Born Haemoparasitic Disease in Ethiopia: A Review. Acta Parasitologica Globalis 7 (1): 12-20.

33. Nuto, Y., Amevoin, K., Koumaglo, H. K., \& Glitho, I. A. (2008). Demonstration of the repellent and toxic effects of Clausena anisata essential oil on flies and ticks. African Journal of Health and Animal Production 6(2): 101-105. French

34. Okunade, A. L., \& Olaifa, J. I. (1987). Estragole: An Acute Toxic Principle from the Volatile Oil of the Leaves of Clausena anisata. J. Nat. Prod. 50 (5): 990-991. hptt://dx.doi.org./10.1021/np50053a046.

35. Outtara, H., Meite, A., Dally, T., \& Kati-Coulibaly, S. (2016). Study of the properties of three

Arecaceae fruits: Elaeis guineensis 
jacq., Cocos nucifera L., Borassus flabellifer Var. J. Appl. Biosci. 105: 10157-10169. French

36. Pazinato, R., Volpato, A., Baldissera, M. D., Santos, R. C. V., Baretta, D., Vaucher, R. A., Giongo, J. L., Boligon, A. A., Stefani, L. M., \& Da Silva, A. S. (2016). In vitro effect of seven essential oils on the reproduction of the cattle tick Rhipicephalus microplus. Journal of Advanced Research 7: 129-134. https://doi.org/10.1016/j.jare.2016.05.003

37. Roma, G. C., Furquim, K. C. S., Bechara, G. H., \& Camargo-Mathias, M. I. (2010). Permethrin-induced morphological changes in oocytes of Rhipicephalus sanguineus (Acari: Ixodidae) semi-engorged females. Food and Chemical Toxicology 48(3): 825-830. https://doi.org/10.1016/j.fct.2009.12.016

38. Stachurski, F. (2007). The footbath acaricide. CIRDES fact sheets; sheets $\mathrm{n}^{\circ} 1,8$ pages, Ouagadougou, Burkina Faso.

39. Vial, L. (2008). Ticks and transmitted diseases. Module "Biology and vector control". UMR 1309 INRA / CIRAD - Bios Department «Control of exotic and emerging diseases». oglass.free.fr/images1/Tiques_Vial.pdf. French

40. Vinturelle, R., Mattos, C., Meloni, J., Nogueira, J., Nunes, M. J., Vaz, Jr. I. S., Rocha, L., Lione, V., Castro, H. C., \& das Chagas, E. F. (2017). In Vitro Evaluation of Essential Oils Derived from Piper nigrum (Piperaceae) and Citrus limonum (Rutaceae) against the Tick Rhipicephalus (Boophilus) microplus (Acari: Ixodidae). Biochemistry Research International vol. 2017, Article ID 5342947, 9 pages, 2017. https://doi.org/10.1155/2017/5342947.

41. Walker, A. R. (2014). Ticks and associated diseases: a retrospective review. Med. Vet. Entomol. 28(1): 1-5. https://doi.org/10.1111/mve.12031

42. Walker A. R., Bouatour J. L., Camicas A., Estrada Pena I.G., Horak A. A., Latif R. G., Pegram R. G., \& Preston P. M. (2014). Tick of domestic animals in Africa: A Guide to identification of species. Bioscience Reports, International Consortium on Ticks and Tick Borne Diseases: Edinburgh, Scotland, U.K., 228p. https://www.researchgate.net/publication/265412942

43. Wigglesworth V. B. (1972). The Principles of Insect Physiology, $7^{\mathrm{e}}$ éd. Chapman and Hall. https://www.amazon.com/Principles-Insect-Physiology...Wigglesw...

44. Yessinou, R. E., Adinci, J., Sessou, P., Adehan, S., Tonouweha, A., Akpo, Y., Adoligbe, C., Assogba, M. N., Koutinhouin, B., Youssao, A. K. I., \& Farougou, S. (2016). In vitro acaricidal effect of Syzygium aromaticum and Cymbopogon citratus essential oil on 
engorged female of cattle tick Rhipicephalus microplus in Benin. Scientific Journal of Veterinary Advance 5(3): 80-86.

https://doi.org/10.14196/sjva.v5i3.2155

45. Yonow, T. (1995). The Life-cycle of Amblyomma variegatum (Acari: Ixodidae): a Literature Synthesis with a View to Modelling. International Journal for Parasitology 25(9): 1023-1060. https://doi.org/10.1016/0020-7519(95)00020-3 